\title{
Território de afetos: práticas femininas antirracistas nos quilombos contemporâneos do Rio de Janeiro
}

\author{
Mariléa de Almeida* \\ ORCID iD 0000-0001-6015-3226 \\ Núcleo de Pesquisa da Mandata Quilombola, Assembléia Legislativa do Estado de São Paulo, São Paulo, Brasil
}

\begin{abstract}
Resumo: A visibilidade atual das mulheres quilombolas é o ponto de partida deste artigo que pergunta sobre os modos femininos de fazer política, especialmente a dimensão antirracista dessas açôes. O recorte temporal parte do final de 1980, quando foi criado o direito territorial para as comunidades remanescentes de quilombo. O trabalho focaliza práticas de quilombolas do Rio de Janeiro que, ao transmitirem saberes, fortalecem os laços entre as pessoas e os territórios onde vivem. Essas açôes, compreendidas como territórios de afetos, ampliam espaços de subjetivação por meio dos deslocamentos de sentimentos provocados pelos dispositivos racistas, sexistas e classistas que incidem sobre seus corpos e territórios.
\end{abstract}

Palavras-chave: Mulheres quilombolas. Práticas antirracistas. Território. Afetos.

\section{Territory of affection: anti-racist female practices in the contemporary quilombos of Rio de Janeiro}

Abstract: The current visibility of quilombola women is the starting point of this thesis that asks about feminine ways of doing politics, especially the anti-racist dimension of their practices. The timeframe starts in the late 1980s, when the territorial rights of the descendants of quilombola communities were created. The work focuses on the practices of quilombola women from Rio de Janeiro, who, in transmitting knowledge, strengthen the bonds between people and the territories they inhabit. These actions, understood as territories of affection, expand spaces of subjectivity through the shifting feelings provoked by racist, sexist and classist dispositifs that affect their bodies and territories.

Keywords: Quilombola women. Anti-racist practices. Territory. Affection.

Doutora em História pela Universidade Estadual de Campinas (Unicamp). E-mail: marileaatm@ gmail.com. 


\section{Apresentação}

Faz tempo que a imagem dos quilombos tem sido utilizada para evocar a resistência antirracista, bem como propor um modelo societário a ser seguido. ${ }^{1}$ Até o século xx, o tropo predominante sobre a resistência quilombola valorizava experiências masculinas em termos de virilidade, violência e força. Entretanto, nas últimas três décadas, estamos presenciando transformaçôes nos significados atribuídos à resistência quilombola.

A recente visibilidade e o reconhecimento do protagonismo das mulheres quilombolas na luta pela terra exprimem que o conteúdo dessas mudanças incorpora a dimensăo de gênero. Esse acontecimento histórico materializa-se em inúmeros trabalhos acadêmicos, documentários e matérias jornalísticas. ${ }^{2}$ Destaca-se, em 2020, a publicação do livro Mulheres quilombolas: territórios de existências negras femininas. A obra coletiva escrita por dezoito mulheres quilombolas apresenta teorizaçóes que acontecem rente aos corpos nos enfrentamentos com a violência que incide sobre seus territórios, suas comunidades e suas corporeidades (Dealdina, 2020). Nas últimas três décadas, as mulheres quilombolas deslocaram-se da invisibilidade e ocuparam a cena pública como autoras de suas histórias.

Esse percurso histórico é narrado em minha tese Territórios de afetos: práticas femininas antirracistas nos quilombos contemporâneos do Rio de Janeiro, defendida em 2018, no programa de pós-graduação em História da Universidade Estadual de Campinas (Unicamp). Em linhas gerais, o trabalho pergunta sobre as novidades que as práticas de mulheres quilombolas têm trazido para o fazer político, especialmente para os campos dos antirracismos e dos feminismos. O arco temporal parte do fim de 1980, quando foi criado o direito territorial para as comunidades remanescentes de quilombo, chegando até a primeira década dos anos 2000, quando ocorre, de forma simultânea e paradoxal, a ampliação de políticas públicas em territórios quilombolas e o crescente processo de burocratização de acesso ao direito territorial.

Durante a pesquisa, realizada nas comunidades quilombolas do Rio de Janeiro, entrevistei 48 quilombolas, a maioria mulheres negras cisgênero, de idade e tom de pele diversificados. Igualmente variadas eram as formaçôes acadêmicas, filiaçôes políticas e práticas religiosas. Algumas delas concederam-me entrevistas que seguiram a linha do relato de vida, enfocando as práticas mobilizadas durante os processos de engajamento na luta quilombola. Em geral, os temas relacionados ao racismo e ao sexismo surgiram

1 Uma proposta que articula a militância política à dimensão conceitual de quilombo é o conceito de quilombismo, criado por Abdias do Nascimento, nos anos 1980. Trata-se de um projeto político que pretende aglutinar os movimentos negros em torno do modelo coletivista de Palmares (Nascimento, 2019); destaca-se igualmente a abordagem da historiadora Beatriz Nascimento, que abordou o quilombo como tecnologia política, banto e instrumento vigoroso no processo de reconhecimento da identidade negra brasileira (Nascimento, 2018).

2 Entre trabalhos acadêmicos e livros, destaco Prates (2015), Böschemeier (2010), Cunha (2009) e Silva (2019); entre os documentários, destaco Dandaras (2015) e Raça (2012). 
nesses encontros sem que eu os tivesse provocado. Muitas vezes, percebi que meu corpo de mulher negra, com meu cabelo crespo, era um facilitador para que as mulheres começassem a falar comigo sobre esses temas. Suas reaçóes, entretanto, eram diversas: passaram pela admiração, pelo espanto, pela curiosidade - e até pela desconfiança. Em alguns casos, elas destacavam o fato de eu ser a primeira ou estar entre as poucas pesquisadoras negras com quem tiveram contato.

Para as finalidades deste artigo, cujo objetivo central é tornar visível os usos da transmissão da história por meio da oralidade como uma prática antirracista pelas mulheres quilombolas, o texto se desdobra em três eixos analíticos. $\mathrm{O}$ primeiro descreve, em linhas gerais, as condições históricas que favoreceram a visibilidade contemporânea das mulheres quilombolas. $\mathrm{O}$ segundo detalha as bases teóricas que embasam a abordagem sobre o conceito territórios dos afetos. E por fim, no terreno das práticas, percorro a trajetória de Marilda de Souza, liderança do Quilombo de Bracuí, situado em Angra dos Reis (RJ). Marilda é contadora de história, reconhecida como uma guardiã da memória coletiva do grupo.

\section{As condições históricas}

Até o início da década de 1990, o termo quilombo, atávico à experiência de Palmares, era identificado como um ato de resistência pensado nos termos da cultura masculina (guerra, violência, virilidade). Falar de quilombo significava tratar dos heroicos atos de homens como Zumbi dos Palmares, Ganga Zumba, Manoel Congo, entre outros. Em 1988, quando se criou na Constituição Federal o direito territorial dos chamados "remanescentes das comunidades de quilombos", a resistência quilombola era pensada, com raras exceçóes, ${ }^{3}$ por meio de uma perspectiva masculina e bélica. De todo modo, a promulgação do direito, na forma do artigo 68 do Ato das Disposiçôes Constitucionais Transitórias (ADCT), foi comemorada como uma vitória da luta antirracista, já que, de forma inédita, a legislação concedia o direito a setores da população negra. Entretanto, durante quase uma década após a criação do dispositivo jurídico, a aplicabilidade da lei ainda esbarrava na definiçáo tradicional de quilombo, entendido como um lugar isolado onde os negros se refugiavam. Acreditava-se, então, que existiam poucos grupos que poderiam reivindicar esse direito.

Ao longo da década de 1990, essas premissas começam a ser rasuradas, seja em relação aos significados do termo quilombo e à quantidade de comunidades que poderiam solicitar esse direito, seja sobre a visão de que o dispositivo jurídico representava uma mudança de mentalidade na forma como as instituiçóes brasileiras

Sobre a exceção, destaco a pesquisa da historiadora Beatriz Nascimento que, no fim dos anos 1970, apontava outros aspectos da resistência quilombola. Dentre eles, a importância do que ela definiu como 
reconheciam o peso do racismo na perpetuação das injustiças sociais.

Sobre os significados de quilombo, as mulheres e as práticas culturais identificadas como femininas foram sendo, aos poucos, selecionadas como os novos símbolos da terra. Esse processo se reforçou conforme, na batalha discursiva, passaram a ser reivindicadas as relaçóes que se estabelecem com o território e não apenas comprovaçóes materiais e arqueológicas da origem histórica do grupo. Se, por um lado, os novos sentidos do termo permitiram o reconhecimento de inúmeros grupos como quilombolas, por outro, a identidade construída sob uma ideia estática de tradição cultural não significou o acesso imediato ao direito territorial, tampouco trouxe transformaçóes significativas das condiçôes de vida das comunidades que passaram a se autodefinir como quilombolas.

Durante toda existência do direito quilombola, a instabilidade tem regido o tom das políticas públicas. Essa situação foi detalhada pela pesquisadora Allyne Andrade e Silva (2020) em sua pesquisa sobre o Programa Brasil Quilombola (РBQ). O programa foi criado, em 2004, com o objetivo de implementar políticas públicas interinstitucionais destinadas a essas populaçôes. Em que pese a inovação da proposta, conforme detalha a pesquisadora, desde sua criação, о $\mathrm{PBQ}$ foi objeto de disputas políticas e de progressivos esvaziamentos orçamentários. Em 2016, o golpe parlamentar que levou ao poder Michel Temer igualmente atingiu as comunidades quilombolas, culminando com o encerramento do $\mathrm{PBQ}$.

A ineficácia e a descontinuidade das políticas públicas materializam-se, inclusive, pela discrepância sobre o quantitativo de comunidades existentes no país. A Fundaçáo Palmares, até novembro de 2018, havia certificado 3.212 comunidades quilombolas. ${ }^{4}$ Em janeiro de 2021, o relatório publicado pelo grupo de pesquisa Afro, do Centro Brasileiro de Análise e Planejamento (Cebrap), sugere que número de comunidades quilombolas pode chegar a 6 mil. Essa conclusão ocorre a partir da análise de dados preliminarmente divulgados pelo Instituto Brasileiro de Geografia e Estatística (IвGE) que, em 2020, realizou um levantamento dos territórios quilombolas (Arruti et al., 2021). A consolidação dos dados da pesquisa do IBGE servirá de base para a realização do primeiro censo demográfico sobre os territórios quilombolas, informação incontornável para o desenho eficaz de políticas públicas.

De todo modo, a expressividade numérica dos territórios quilombolas é diametralmente oposta à quantidade de titulaçôes obtidas. Segundo o Instituto Nacional de Colonização e Reforma Agrária (Incra), responsável pela titulação dos territórios

"paz quilombola". Para a autora, um quilombo como o de Palmares, entre um ataque e outro da repressão oficial, mantinha-se ora retroagindo, ora se reproduzindo. E os tempos de paz eram fundamentais para a longevidade dos quilombos, porque permitiam a reprodução dos seus modos de vida (Nascimento, 2018).

4 Fundação Cultural Palmares. Quadro geral de comunidades remanescentes de quilombos (CRQs), 2018. Disponível em: http://www.palmares.gov.br/wp-content/uploads/2015/07/quadro-geral.pdf. Acesso em: 14 ago. 2021. 
tradicionais quilombolas, entre os anos de 2005 e 2018, apenas 278 foram contemplados com a elaboração do Relatório Técnico de Identificação e Delimitação (RTID), uma das primeiras e mais importantes etapas do moroso processo de regularizaçáo territorial. No mesmo período, somente 124 comunidades tiveram a titulação de seus territórios. ${ }^{5}$

Apesar da atual inexistência de dados oficiais atualizados sobre as comunidades quilombolas, em 2013, o relatório do Programa Brasil Quilombola detalhou a situação de precariedade em que vivem as comunidades certificadas como quilombolas (Brasil, 2013, p. 16). Das 80 mil famílias quilombolas constantes no Cadastro Único (CadÚnico), sistema que serve de banco de dados para programas sociais, o documento indicou que $74,7 \%$ viviam em extrema pobreza. O relatório também apontou que os quilombolas tinham menos acesso a serviços básicos, como saneamento e energia elétrica, quando comparados ao restante da populaçáo. Entre os quilombolas, 48,7\% viviam em casas com piso de terra batida, $55,21 \%$ não contavam com água encanada, $33,06 \%$ não tinham banheiro, e $15,07 \%$ deles só contavam com esgoto a céu aberto. Havia, ainda, alto índice de analfabetos: $24,81 \%$ não sabiam ler, e, em 2013, a taxa de analfabetismo dentro das comunidades quilombolas era quase três vezes mais alta do que a média nacional, de 9,1\%, apontada pela Pesquisa Nacional por Amostras de Domicílio (Pnad).

Os números expressam como o desamparo social é consequência da forma predominante de governar os corpos daqueles que vivem nas comunidades quilombolas, impondo-lhes condiçóes desumanas. Essa situação evidencia como o racismo governa as condutas por meio de tecnologias de poder que permitem a agressão e justificam a destruição corporal e simbólica daquelas populaçôes, já que, quando se trata dos territórios quilombolas, estamos falando de uma série de práticas, saberes e valores que se perdem diante das dificuldades de continuar vivendo a partir de seus modos de vida tradicionais.

\section{Encruzilhadas teóricas: território, afeto e política}

As condiçóes materiais colocam em risco a continuidade dos modos de vida. Náo por acaso, que várias mulheres quilombolas se valem da transmissão de saberes como forma fortalecer os vínculos entre as pessoas e os territórios. Suas práticas mobilizam o que denomino de território de afeto, entendido como um campo de açáo política que se exprime pela manutenção, criação ou redefinição de espaços potencializados para aqueles que vivem nos territórios quilombolas. Territórios de afetos não são definidos pela identidade jurídica quilombola, mas pela relação que se estabelece com o lugar

INCRA - Instituto Nacional de Colonização e Reforma Agrária. Relatório Técnico de Identificação e Delimitação (RTID): resultado anual de 2005 a 2018, 2019. Disponíveis em: https:/www.gov.br/incra/ pt-br/assuntos/governanca-fundiaria/andamento_processos.pdf. Acesso em: 14 ago. 2014. 
e com aqueles que nele vivem. Trata-se de uma atitude política, que privilegia o uso de saberes como forma de ampliar espaços de subjetivação, constituídos por meio dos deslocamentos de sentidos que essas mulheres realizam em relação aos efeitos das exclusóes de raça, de classe ou de gênero que afetam seus corpos e os territórios de suas comunidades. Lanço máo do termo afeto no caminho aberto por Espinosa, ou seja, as afecçóes do corpo, pelas quais sua potência de agir é aumentada ou diminuída, estimulada ou refreada, e, ao mesmo tempo, as ideias dessas afecçóes (Espinosa, 2013, p. 163-77).

Socialmente nomeamos sensaçóes que atravessam os nossos corpos como amor, raiva, medo, mas vale dizer que os afetos não se confundem com o que chamamos de sentimentos. Os afetos sáo intensidades que atravessam os nossos corpos e muitas vezes não conseguimos nomear, mas que mobilizam nossos gestos, açôes e pensamentos.

Nos últimos anos, em termos teóricos, cada vez mais se reconhece nas Ciências Sociais a importância do afeto ao lado da razão, do cálculo e da estratégia nas múltiplas dinâmicas da vida, incluindo a política. Esse tem sido o fundamento teórico central do que atualmente denominamos virada afetiva. Nos Estados Unidos, desde a década de 1990, e no Brasil, nos últimos anos, a abordagem tem sido usada pelas teorizaçôes feministas e queer. Apesar das diferentes filiaçóes teóricas em torno da virada afetiva, há, pelo menos, duas convergências que merecem destaque: primeira, a rejeição de uma hierarquia entre mente e corpo para a construção do conhecimento. (Almeida, 2018); segunda, o enfoque tanto em nosso poder de afetar o mundo a nossa volta, quanto o de sermos afetados por ele (Hardt, 2015).

As dores e os traumas narrados permitem visualizar os deslocamentos dos afetos tristes em direção aos afetos que potencializam a ação, o que leva a pensar sobre a importância da criaçáo de espaços outros de subjetivaçáo. Por isso, a abordagem de território que atravessa este trabalho engloba, a um só tempo, três dimensôes que não estáo apartadas entre si, mas que, para fins de visualização, descrevo nos seguintes termos: a materialidade física das relaçôes que as quilombolas estabelecem com o território do quilombo; a materialidade simbólica dos significados que atribuem aos espaços; e, por fim, a materialidade subjetiva dada pela abertura de espaços de deslocamento de sentido de discursos racistas, sexistas e classistas. Por essa articulaçáo, são valiosas as reflexóes propostas por Muniz Sodré, que, ao falar das especificidades dos territórios negros, considerou:

A territorialização é de fato dotada de força ativa. Se isso foi historicamente recalcado, deve-se ao fato de que a modelização universalista, a metafísica da representação, opóe-se a uma apreensão topológica, territorializante do mundo, ou seja, a uma relação entre seres e objetos em que se pense a partir das especificidades de um território. (Sodré, 1988, p. 13).

Sodré, cuja abordagem sobre território questiona os modelos teóricos que tendem 
a pensar os espaços como homogêneos e fixos em suas funcionalidades, define território em termos de porosidade, uma vez que seria dotado de uma força ativa, o que implica tomar os territórios em termos de multiplicidade e deslocamentos, bem como as afecçôes que eles provocam. É uma discussão que nos leva às intrínsecas relações entre espaço e subjetividade.

Para abordar as motivaçóes do presente que conduzem a luta quilombola, inspiro-me, de igual modo, na abordagem de Givânia Maria da Silva, quilombola e pesquisadora da educação do Quilombo Conceição das Crioulas, situado em Salgueiro (PE), que diz:

Partindo dessa perspectiva, pensar quilombo como 'o presente', é necessário nos despir dos conceitos de quilombo apenas como algo ligado ao passado estático e reconhecê-lo no hoje. Essa visão estática não reconhece as mudanças que ocorreram, ora por força das organizaçóes próprias dos quilombos, ora pelas novas formas de escravização. Só a partir de uma compreensão nova, em que se considere a diversidade quilombola, suas características e especificidades culturais, regionais, geográficas e políticas é que podemos compreender melhor quem são os quilombos, suas lutas e resistências como estratégias de construção de seus modelos de desenvolvimento e processos organizativos próprios. É preciso pensar em um presente que coloque o Estado brasileiro na condiçáo de agente devedor, mas, ao mesmo tempo, responsável pela elaboração e execução das políticas públicas para as comunidades quilombolas, rompendo com as marcas do passado escravo que as colocou em situação de desigualdade. (Silva, 2012, p. 37-38).

Os territórios de afetos, concebidos como criaçôes do presente, referem-se às práticas construídas pelos deslocamentos dos sentimentos relacionados tanto à materialidade da terra - seja o medo de perdê-la, seja o cansaço da espera jurídica, seja o orgulho de preservá-la - quanto aos dispositivos dominantes de poder, que se baseiam nas exclusôes de raça, gênero e classe. A fim de visualizarmos os usos da história e da oralidade como uma experiência que evoca territórios afetivos, seguiremos pelas trilhas construídas por Marilda de Souza Francisco.

\section{História e reparação: as práticas de Marilda de Souza Francisco}

Marilda é uma liderança quilombola respeitada, dentro e fora da comunidade, por ter se constituído como um arquivo vivo das histórias locais, partilhando-as pela oralidade. A primeira vez que estivemos juntas foi no finalzinho da tarde de 24 de fevereiro de 2016. Naquele dia, Angélica de Souza Pinheiro, outra liderança do quilombo, que lamentavelmente veio a falecer em setembro de 2016, levou-me até a casa de Marilda para 
que eu fizesse os primeiros contatos. ${ }^{6}$ No caminho, Angélica mencionou que a irmã de Marilda, Maria Lúcia, estava hospitalizada e que ela vinha a acompanhando no hospital. Diante disso, imaginei que o encontro seria breve, apenas para agendarmos uma conversa futura, a ser realizada em momento mais conveniente. Quando lá chegamos, à medida que iniciamos informalmente as apresentaçóes, Marilda começou a contar histórias que envolviam a irmã e outros integrantes da comunidade. Aos poucos, enquanto falava, percebi como o semblante de preocupação dava lugar a uma expressão mais descontraída. Naquele instante, intuí que estava diante de uma contadora de histórias.

Marilda nasceu em 15 de fevereiro de 1962, em Angra dos Reis, nas mesmas terras que, em 1878, foram doadas no testamento do comendador José de Souza Breves para o grupo de ex-escravos e escravas da fazenda. Durante a infância nos terreiros do Bracuí, além das brincadeiras e travessuras, ela ouvia a forma como seu pai, Antônio Francisco Ramos, contava histórias. Um jeito, segundo ela, cheio de alegria. Aos poucos, Marilda foi desejando recontá-las de seu jeito. Eram histórias do tempo do cativeiro, dos desembarques clandestinos, da doação das terras feita no fim do século XIX, das condiçôes de vida no pós-abolição, das grilagens e das pressōes para que seus familiares abandonassem o território. Também eram histórias de fantasmas, assombraçóes, descoladas da necessidade de semelhança com a realidade.

No Bracuí, as narrativas sobre o passado estão presentificadas não apenas nas paisagens, mas também nos corpos que recontam essas histórias. Bracuí é terra de griots e griottes, ou seja, lugar de inúmeros contadores de história.7 Foi nessa terra que Marilda aprendeu tais histórias, mas foram as condiçōes históricas em torno da construção da diferença quilombola que favoreceram o reconhecimento do valor dos saberes que ela possuía. Naquele momento, ela foi construindo novos significados para as histórias contadas por seu pai, conferindo-lhes a potencialidade política de criar laços entre as pessoas e o espaço onde vivem, além de concebê-las como algo fortalecedor da autoestima para aqueles que moram no Bracuí. A esse respeito, Marilda explica: "então a nossa luta continua sendo pela conquista da terra e o fortalecimento da comunidade,

6 Em setembro de 2016, Angélica de Souza Vieira faleceu por complicações renais. Ela havia se formado na primeira turma de Licenciatura em Educação do Campo, pela Universidade Federal do Rio de Janeiro (UFRRJ), em 2011. Angélica também era jongueira e uma liderança ativa da associação quilombola foi ela quem me apresentou a outras lideranças femininas do Bracuí. Em 2017, durante o Seminário Mulheres em Movimento, promovido pelo Sindicato Estadual dos Profissionais da Educação (Sepe) e pela Associação dos Remanescentes de Quilombos Santa Rita do Bracui - Angra dos Reis (Arquisabra), Angélica foi lembrada como uma das mulheres de luta do quilombo.

7 Embora os termos griot (ou griô) e griotte sejam usados para fazer referência às oralidades negras em múltiplos contextos diaspóricos, a prática tem sua origem no oeste da África e remonta ao século XIII, durante o Império Mali. No século XIX, viajantes franceses que frequentavam a região do Senegal usaram o termo griot para definir contadores de história da região. Segundo Thomas Hale (1994), a prática, até o fim do século XIX, estava exclusivamente associada aos homens, havendo pouca referência às griottes, ou seja, à tradição de contar histórias entre as mulheres. A narrativa dos griots, enfatizando apenas as práticas masculinas, pode ser visualizada em Hale (1994) e Leila Hernandez (2005). 
das pessoas, tipo educação mesmo, autoestima, porque nós negros temos muita baixa estima pelo que aconteceu nos tempos passados" (Marilda de Souza Francisco, 2014).

Do enunciado acima, destaco a articulação entre a luta pela terra e a necessidade de fortalecimento da autoestima por meio da educação. É uma percepção acurada de que o racismo não implica apenas privaçáo material e de direitos, mas também afeta o que há de mais subjetivo: a capacidade de visualizaçáo das próprias potencialidades. Para isso, é preciso elaborar o trauma "pelo que aconteceu nos tempos passados", uma atitude corajosa de enfrentamento da dor. A análise de bell hooks, tratando da dimensáo do trauma na experiência negra estadunidense, converge com a percepção de Marilda:

Em toda a história de nosso país, negros e sociedade como um todo quiseram minimizar a realidade do trauma na vida do negro. Isso tem sido fácil a qualquer um que se concentra nos assuntos relativos à sobrevivência material e vê sua privação como a razão principal da continuidade de nosso caráter coletivo de subordinação, em vez de se situar no tema do trauma e recuperar nossas pautas. (hooks, 2003 p. 23). ${ }^{8}$

Notemos como hooks indica, tal qual Marilda, que a elaboração do trauma deve estar incluída nas agendas de reivindicaçóes da luta antirracista, que as necessidades materiais devem estar entrelaçadas às subjetivas. Para ela, o conhecimento histórico tem sido um dos meios de compreender as injustiças e reelaborar a dor. A exemplificar essa percepçáo, vejamos um trecho em que a griotte do Bracuí narra uma conversa que teve com sua irmã:

A minha irmá falava assim: 'poxa, quando eu cresci, às vezes eu me revoltava por ser negra, porque eu não via um negro rico, eu não via um negro com carro. Só via o negro sempre lutando muito para ter alguma coisa. Agora eu olhava as outras pessoas de cor branca e num instante as pessoas tinham uma casa boa'. Aí eu fui falando para ela assim: 'Maria Lúcia, até os italianos que vieram depois ganharam terra e plantaram [...], mas, minha filha, eles [os negros] tinham condiçóes de escravos e depois quando eles foram libertos eles continuaram não tendo nada!' (Marilda de Souza Francisco, 2016).

Maria Lúcia Oliveira, irmã mais velha de Marilda pela parte materna, é capelã na igreja da comunidade, ou seja, responsável pelos ofícios religiosos, além de jongueira, sendo alguém por quem Marilda expressa respeito e admiração. No seu dizer, elas desenvolveram uma relaçáo de amizade, em que conversas como as acima são frequentes. Ali, Marilda desloca o ressentimento manifestado pela irmá, valendose do conhecimento histórico para explicar as desigualdades entre negros e brancos.

8 Tradução livre da autora. 
Em sua fala, os negros não podem se sentir mal por aquilo que não receberam - uma abordagem que permite a elaboração dos traumas individuais e coletivos, favorecendo tanto a criação de espaços outros de subjetivaçáo como a denúncia de injustiças. Nessa segunda dimensão, parafraseando Conceição Evaristo, as narrativas, para Marilda, não se destinam a "ninar os sonhos da casa-grande, e sim incomodá-los em seus sonos injustos" (2007, p. 21).

Para Marilda, seu engajamento político teve início nos anos 1980, especialmente nas reunióes de grupos de jovens de que participava junto à igreja católica. A aproximação do grupo do Bracuí com setores progressistas católicos se relaciona à tentativa de expulsão dos moradores por duas empresas, a Bracuhy e a Sonial, cujos interesses residiam na indústria do turismo e visavam investimentos nas terras litorâneas onde vivia parte dos moradores do Bracuí. Naquela época, setores progressistas ligados à teologia da libertaçáo funcionavam como aglutinadores de demandas sociais, por meio das comunidades eclesiais de base ou da Pastoral da Terra. Mas foi o ativismo quilombola, na década de 1990, que permitiu que ela visualizasse a potencialidade das narrativas orais na luta pela terra. Em Bracuí, essa aproximaçáo começou na década de 1990, liderada pelo jovem Leandro da Silva Ramos, a partir de seus contatos com lideranças do Quilombo de Campinho da Independência, primeira comunidade a ter as terras tituladas, em 1995. Por meio dessas trocas, Leandro foi compreendendo o direito das comunidades negras rurais e os procedimentos que o grupo de Bracuí deveria realizar. Desencadeou-se, entáo, um trabalho junto à comunidade para que se compreendesse a questáo quilombola nos termos jurídicos contemporâneos. Sobre isso, Leandro, que na época tinha 24 anos, narrou, no relatório de identificaçáo da comunidade: "Muita gente não acreditava que aquilo era pra gente! Gente com medo de ser enganada, de ser mais grileiro chegando na regiáo pra tomar as terras da gente! De tão calejados ficaram muito desconfiados. Só com o tempo é que ganharam mais confiança" (Mattos et al., 2009, p. 77).

Marilda estava entre os moradores do Bracuí que rapidamente se engajaram no processo de aquilombamento da comunidade, não deixando, portanto, que a percepção calejada do passado bloqueasse as possibilidades do presente. Seu envolvimento derivou tanto do acúmulo de experiência política nas organizaçóes de base da igreja católica, como do reencontro pessoal com as histórias locais, durante sua participaçáo em um projeto desenvolvido na escola da comunidade, onde trabalhava como zeladora.

Em 1992, a diretora da escola Áurea Pires da Gama, da comunidade de Santa Rita do Bracuí, convidou Marilda para colaborar com o projeto Descobrindo as Histórias Locais, cujo objetivo era levantar as histórias do território onde a escola está situada. $\mathrm{O}$ trabalho estava vinculado à Secretaria Municipal de Educaçáo de Angra dos Reis, que, inspirada pela proposta de Paulo Freire, incentivou a construção de práticas pedagógicas que tomassem as experiências dos alunos como ponto de partida. Vale lembrar que, nesse município, o Partido dos Trabalhadores (рт) conseguira se 
reeleger em 1992, o que permitiu a continuidade de iniciativas da área educacional com viés popular. No projeto, Marilda ficou responsável em levar e acompanhar a equipe pedagógica da escola até os moradores mais velhos, a fim de que contassem as histórias locais. Os esforços culminaram com a construçấo dos livros Bracuí: conhecer para amar, produzido mais artesanalmente, e Bracui, sua luta, sua história, que recebeu duas ediçóes, uma em 2000 e a outra em 2004.

Nesse ir e vir pelas casas, Marilda foi construindo sentidos outros para as histórias que ouvia de seu pai: "Na verdade, eu comecei a descobrir que essas histórias tinham valor para educação", disse-me. No trecho abaixo, ela mesma descreve o processo:

Fomos no seu Adriano, no seu Manoel Moraes, pessoas mais velhas. Dona Joana, que já faleceu. Aí eu falei assim: meu pai contava muito essas histórias também, e eu sempre gostei de ouvir, sentada na beira do fogáo. Aqui não tinha luz, aqui não tinha televisão, não tinha nada, e meu pai gostava de contar as histórias. [...] E, entâo, foi onde eu descobri que eu lembrava também de várias coisas, de várias histórias que meu pai contava. Então, a gente foi fazendo um apanhado de tudo isso e foi transformando em livro. [...] Muitas histórias que meu pai contava, eu achava que era da cabeça dele. Eu achava que ele tinha inventado, mas não era, não: era história mesmo que aconteceu no local. Várias pessoas contavam a mesma história, com outras palavras ou com outros jeitos, mas era a mesma história. (Marilda de Souza Francisco, 2016)

Do longo trecho acima destaco o momento em que Marilda começa a intuir que as histórias de seu pai não eram invenção - faziam referência a acontecimentos efetivamente ocorridos naquelas terras no passado. Brincando sobre a decepção de descobrir que seu pai não havia criado aquelas histórias, ela ressalvou: "Não foi meu pai que inventou. Toda família contava a mesma história do negro fujão, só que cada família dava o seu final".

De casa em casa, Marilda viu que alguns temas se repetiam, como o desembarque clandestino de escravos no século xix; a doação das terras da Fazenda de Santa Rita do Bracuí aos escravos, no período que antecede a abolição da escravatura; as inúmeras tentativas de retirada das terras do grupo no pós-abolição; os atos de ousadia dos negros e das negras do Bracuí, no período da escravidão ou após o fim do regime escravocrata. Uma história local que se conecta com a história do mundo:

Também a história oral do lugar, querendo ou não, está ligada à história do Brasil e está ligada de certo modo à história do mundo. Quando a gente vê um filme do negro da África que foi para outros países, eu fico pensando que é a mesma história nossa [do Quilombo do Bracuí]. O negro saiu do seu continente e foi para vários lugares e teve os mesmos tratamentos. (Marilda de Souza Francisco, 2016).

Marilda narra como a história oral local se conecta com a perspectiva diaspórica, 
já que sublinha similitudes entre as experiências negras por conta do tráfico atlântico. Ao assistir em um filme a experiência negra em outros países, ela a conecta com as histórias orais que circulam no Quilombo do Bracuí. Esse processo favoreceu que Marilda enxergasse o que estava debaixo de seu nariz, ainda que opaco: a comunidade do Bracuí tinha uma história que fazia parte da narrativa da escravidáo do Brasil e do mundo, e o melhor: muitos da localidade sabiam contá-la, inclusive ela mesma:

Eu me reconheci nelas. Algumas histórias que eles contavam, eu sabia também. Pra mim, aquilo não tinha importância. Não tinha. Eu ficava assim: gente, mas como? Eu também sei disso. Já tive a oportunidade de ver, de ouvir essas histórias. [...] Aí eu fiquei assim: eu também sei falar isso. Não foi fácil assim. [Pensava:] 'Eu acho que só tem importância porque as pessoas são mais velhas. Se eu falar, não vai ser tấo importante. Porque eu sou mais nova'. E aí a gente continuou indo nas casas, três a quatro meses. (Marilda de Souza Francisco, 2016).

"Eu me reconheci nelas", diz, aludindo às pessoas mais velhas que ela e o grupo da escola seguiam ouvindo e registrando durante o projeto. Ao ouvir essa frase na varanda de Marilda, as palavras ressoaram em mim como uma poesia, cuja poética indica sua invenção de si como contadora de histórias. Não foi, porém, como ela diz, um processo fácil ou imediato: "Se eu falar, não vai ser tâo importante. Porque eu sou mais nova". Notemos que o questionamento náo gira em torno da habilidade de contar - "eu sabia também" -, mas das condiçôes de ser ouvida. Os mais velhos estavam autorizados pela tradiçáo. Dado que a transmissão de experiência, de hierarquia e do respeito aos mais velhos está imbricada em práticas das tradiçóes culturais afro-brasileiras (Martins, 2016), eles são ouvidos porque são os mais velhos. Outro elemento que poderia impedir sua enunciação era o medo de contar e ser julgada por não ter formação acadêmica:

Porque, até então, eu tinha muita vergonha de falar, de achar que estava falando errado, me preocupar muito em estar falando. E aí depois a gente vai deixando isso pra lá. Falei assim: bom, se eu estou falando errado o pesquisador que arrume! Eu sempre falo, os professores de português não têm interesse de estar fazendo as pesquisas sobre a linguística, essa mistura de comunidades diferenciadas, não? (Marilda de Souza Francisco, 2016).

A vergonha de falar "errado", ou melhor, fora dos padróes da norma gramatical, é um temor que a afligiu no princípio. Todavia, no decorrer do processo, ela foi perdendo a timidez, sugerindo, inclusive, que professores de português pesquisem sobre os diferentes falares da língua. Por meio dessa atitude, Marilda aponta que as pesquisas deveriam ampliar olhares, e náo trazer constrangimentos e hierarquizaçóes dos diferentes registros de oralidade. De certa maneira, sua postura denuncia o preconceito linguístico que atravessa a linguagem e que, como apontou Marcos Bagno, se baseia 
na crença de que a língua portuguesa digna desse nome é aquela "ensinada nas escolas, explicada nas gramáticas e catalogadas nos dicionários", e qualquer prática que escape do triângulo escola-gramática-dicionário é considerada feia, rudimentar e incipiente (Bagno, 1999, p. 40). Nessa perspectiva, um dos efeitos do preconceito linguístico é a interdição, que, segundo Foucault (1996), compóe um dos procedimentos de exclusão dos discursos, baseada na premissa de que nem todos têm o direito de dizer tudo, em qualquer circunstância e sobre qualquer coisa.

Um dos efeitos da interdição sobre os modos de falar de mulheres pobres que não puderam completar a escolarização formal é a própria impossibilidade de terem suas habilidades intelectuais e criativas reconhecidas. Marilda, ao dizer que deixou de se preocupar com os "erros", rasura as interdiçóes de classe, raça e gênero que incidem sobre seu corpo. Considerando o que discutimos até aqui, podemos perguntar: o que mobiliza sua atitude em torno da prática de contar histórias? Em uma de nossas conversas, ela me ofereceu uma possível resposta: "Era uma facilidade que eu comecei a entender que eu tinha, mas nunca assim pra motivo de estudo, nem nada, não. [...] Então, ali contando a história, é quando a gente se sente bem. É gostoso fazer. E eu sempre gostei disso" Marilda de Souza Francisco, 2016).

$\mathrm{O}$ argumento de Marilda é simples: não se trata apenas de cumprir uma missão política ou uma pragmática acadêmica, mas também de ir ao encontro de algo que lhe dá prazer e potencializa sua vida. Com isso, ela problematiza a imagem recorrente sobre mulheres negras, de que o dever é que mobiliza suas ações, concebendo-as como aquelas que estáo no mundo para servir aos outros e renunciar ao prazer.

Priscila Vieira (2013), analisando a concepção de cuidado de si e do outro em Foucault, estabelece uma diferença entre o modelo socrático e a prática dos cínicos. Para a autora, na prática socrática, o cuidado de si e do outro considerava a necessidade de haver uma harmonia entre o discurso e a ação, ou seja, entre aquilo que se diz e o próprio modo de viver. Já entre os cínicos, tratava-se de mostrar a verdade pelo escândalo da própria vida.

A ancestralidade é atualizada no presente como potência por Marilda, já que os antepassados que viveram no quilombo, além dos conteúdos das histórias, deixaram ensinamentos sobre os modos de viver. Em um relato sobre o aspecto das casas no quilombo, ela demonstra a relação que estabelece com o legado do passado:

A ideia de quilombo caiu por terra, não é? [...] Tem alguns que logo falam: 'a gente idealiza o quilombo com aquelas casas de pau a pique, tudo juntinho'. Aí eu falei assim: 'infelizmente, a empresa de tijolo chegou para a gente e falou': 'olha, você tem que fazer a casa de tijolo porque a casa de pau a pique traz doença'. Náo era porque estavam com coisa da gente ficar doente, eles queriam vender tijolo, cimento e telha. [...] Então, é por isso que nossas casas se transformaram tudo em casa de alvenaria, porque, minha filha, se fosse dar doença, dá na casa de alvenaria, dá na casa de pau a pique, dá tudo. Antigamente a gente tinha casa de pau a pique 
e ninguém ficou doente. (Marilda de Souza Francisco, 2016).

Aqui Marilda apresenta duas formas de se aproximar do legado do passado, expresso no modo de habitar. A primeira transforma a ancestralidade em um dispositivo de poder que retira os quilombolas do tempo e do espaço do presente, considerando que suas açóes devam estar movidas pelo interesse por um passado que se apresenta como estático. A segunda, defendida por Marilda, faz uso da tradiçáo como forma de potencializar a vida no presente. Por isso, ao longo da narrativa, ela problematiza a idealizaçáo em torno dos quilombolas, lançando mão do exemplo da casa de pau a pique. A narrativa que romantiza os quilombos preocupa-se com o fim das casas porque ela representa a tradição como invariável. Para Marilda, não se trata de representar ou encenar o passado, mas de mobilizar valores e modos de vida herdados dos antepassados para potencializar o presente. Problematizar as idealizaçóes envolve recuperar as condiçóes históricas que fizeram com que as casas passassem a ser construídas em alvenaria, associando essas transformaçóes à racionalidade capitalista que, com a finalidade de vender material de construção, vendeu a ideia de que a casa de pau a pique trazia doenças. Esse discurso ressoa em transformaçóes atuais na própria comunidade, já que as construçóes eram primeiramente feitas por meio de mutirão. E, com o passar do tempo, foram deixando de habitar dessa maneira. Valendo-se da contextualizaçáo, Marilda mostra como os quilombos são afetados pelas mesmas condiçóes históricas que o conjunto da sociedade: a racionalidade capitalista, que não apenas produz mercadorias, também produz formas de sociabilidade. Outra maneira de pensar sobre os quilombolas é naturalizar as condiçóes de pobreza como se fossem indissociáveis dos corpos negros. Sobre isso, Marilda, em outro momento, relata:

'Ah, mas eu achei que o quilombo era um lugar onde tinha aquelas casas de taipa, muita criança e não sei que lá'. Às vezes, ainda falam assim: 'aquelas crianças descalças, barrigudas, remelentas correndo pra lá e pra cá ou chorando'. Uma vez eu falei para o garoto: 'aquele quilombo, onde tem muita miséria, não é?'. Aí quando você chega aqui e vê um sítio, vocês acham que não é um quilombo, não é? (Marilda de Souza Francisco, 2016).

No trecho acima, ela questiona como a semântica da precariedade cerca o pensar sobre os modos de vida quilombolas. Daí, a necessidade de ir ao quilombo e encontrar "muita miséria", já que essa é a condição naturalizada dos negros. Trata-se de relacionar os quilombos contemporâneos às narrativas de assujeitamento do passado escravista, pensamento que, segundo Marilda, também permeava a comunidade de Santa Rita do Bracuí, antes de entender do que se tratava o direito quilombola:

O próprio quilombola, mesmo, alguns falaram na época: 'Santa Rita vai ser um quilombo. Quilombo é atraso! Vai ter que voltar a trabalhar na roça, não vai poder 
ter mais nada!' Eu falei: 'gente! Ninguém volta no tempo, não'. Aí hoje estamos com o projeto da horta. As pessoas vêm e perguntam se você quer. Não é obrigado a querer, não. (Marilda de Souza Francisco, 2016).

Ela reforça a ideia de que não é possível voltar no tempo. Recentemente, o companheiro de Marilda e seu filho, Marcos Vinícius, retomaram a horta no quintal. Pai e filho têm articulado os saberes dos mais velhos aos conhecimentos que o jovem aprendeu na faculdade, no curso de agroecologia. Em uma conversa, ele me disse que um dos princípios da agroecologia é plantar respeitando o tempo das plantas e das pessoas, o que destoa da temporalidade capitalista da eficiência. Tanto na fala de Marilda como na de Marcos Vinícius aparece o incentivo para que outros moradores voltem a plantar, mas náo como obrigaçáo. Por meio dos dois exemplos, da casa de pau a pique e da horta, observemos que náo se retomam as tradiçóes para encenar o passado, mas para se aproximar dos valores constitutivos de um modo de transmitir a experiência. E que valores são esses?

Tem gente que diz que coisa boa é o lugar que tem sua casa murada. O esgoto correndo na rua, mas se sua casa está murada, ladrilhada, isso que é bom. Eu já gosto mesmo de não ter muro, todo mundo entra, passa e olha. Ô, seu danado você pegou meu cacau! Mesmo que às vezes fica brigando com as crianças, mas eu estou interagindo com as coisas. Agora, a pessoa se esconder atrás de um muro, faz um muro maior do que esse pé de abacate. [...] Eu gosto de minha casa sem muro, sem cerca. [...] Esse é o meu jeito de ver. Gosto da natureza, mas também eu gosto de ir para a cidade, desde que eu vá à cidade e volte pra cá. (Marilda de Souza Francisco, 2016).

Para Marilda, habitar de uma determinada forma está ligado a um modo de viver. Não ter muro significa que as crianças, por exemplo, podem entrar em seu quintal e pegar uma fruta, gerando uma maneira de interagir entre os moradores. Em sua ética, o terreiro, a casa e o corpo estâo integrados. Vemos que a relação com território é afetiva. Ao mesmo tempo, não há um juízo de valor sobre a cidade e o lugar onde vive. A certa altura, ela diz que gosta de ir à cidade, "desde que eu vá e volte pra cá". Valendo-se de práticas de transmissáo da experiência que ocorre por meio da oralidade Marilda recupera narrativas soterradas pela vergonha e pela dor causadas pelo racismo.

Narrar as experiências de mulheres quilombolas, como a de Marilda de Souza, faz parte de uma escolha política, cuja motivação é tornar visíveis, simultaneamente, os dispositivos racistas e sexistas que colocam seus corpos, saberes e territórios sob risco constante, bem como os agenciamentos que, no cruzamento entre ética e política, rasuram as formas convencionais de fazer política, produzindo devires políticos e subjetivos. Não se trata de idealizá-las, tampouco de sugerir que haja um único modelo político a ser seguido. Suas experiências não são exemplares em um sentido moral, mas 
podem ser inspiradoras em tempos em que a racionalidade neoliberal, com sofisticados dispositivos de poder, tende a limitar nossa capacidade de criaçáo de projetos coletivos.

\section{Referências}

ALMEIDA, Mariléa de. Territórios de afetos: práticas femininas antirracistas nos quilombos contemporâneos do Rio de Janeiro. Tese (Doutorado em História) - Unicamp, Campinas, SP, 2018. ARRUTI, José Maurício et al. O impacto da covid-19 sobre as comunidades quilombolas. Informativo Desigualdades Raciais e Covid-19, Afro-Cebrap, n. 6, 2021.

bagno, Marcos. Mito no 4: "As pessoas sem instruçáo falam tudo errado". In: bagno, Marcos. Preconceito Linguistico: O que é? Como se faz? São Paulo: Loyola, 1999. p. 40-45.

BÖSCHEMEIER, Ana Gretel Echazú. Natureza de mulher, marca de mãe, nome de negra: identidades em trânsito e políticas do corpo na comunidade quilombola de Boa Vista dos Negros. Dissertação (Mestrado em Antropologia) - UFRN, Nata, RN, 2010.

BRASIL. Secretaria Especial de Políticas de Promoção de Igualdade Racial. Programa Brasil Quilombola: relatório de gestáo 2012. Brasília: SEPPIR, 2013.

CUNHA, Priscila Bastos. Entre o quilombo e a cidade: trajetórias de individuação de jovens mulheres negras. Dissertaçáo (Mestrado em Educação) - UFF, Niterói, RJ, 2009.

DEALDINA, Selma dos Santos (Org.). Mulheres quilombolas: territórios de existências negras femininas. São Paulo: Sueli Carneiro: Jandaíra, 2020.

ESPINOSA, Benedictus de. Ética. Belo Horizonte: Autêntica, 2013.

EVARISTO, Conceição. Da grafia-desenho de minha mãe: um dos lugares de nascimento de minha escrita. In: alexandre, Marcos Antônio (Org.). Representações performáticas brasileiras: teorias, práticas e suas interfaces. Belo Horizonte: Mazza, 2007. p. 16-21.

FOUCAULT, Michel. A ordem do discurso. São Paulo: Loyola, 1996.

HALE, Thomas A. Griottes: females voices from West Africa. Research in African Literatures, Bloomington, v. 25, n. 3, p. 71-91, 1994.

HERNANDEZ, Leila Leite. O olhar imperial e a invenção da África. In: HERNANDEZ, Leila Leite. A África na sala de aula: visita à História Contemporânea. São Paulo: Selo Negro, 2005. pp. 17-44.

HARDT, Michael. Para que servem os afetos? Intersemiose, Recife, ano 4, n. 7, p. 9-14, jan./jun. 2015.

HOOKS, bell. Healing wounded hearts. In: ноокs, bell. Rock my soul: black people and self-esteem. New York: Atria, 2003. p. 1-20.

MARTINS, Leda Maria. Performances da oralitura: corpo, lugar da memória. Letras, 
Santa Maria, n. 26, p. 63-81, jul./dez. 2016.

MATTOS, Hebe Maria; ABreu, Martha; souza, Mirian Alves; couto, Patrícia Brandão. Relatório antropológico de caracterização histórica, econômica e sócio-cultural do Quilombo de Santa Rita do Bracui. Niterói: UFF; Faculdade Euclides da Cunha; Incra-SRRJ, 2009.

NASCIMENTO, Abdias. O quilombismo: documentos de uma militância pan-africanista. São Paulo: Editora Perspectiva, 2019.

NASCIMENTO, Beatriz Maria do. Beatriz Nascimento, quilombola e intelectual: possibilidades nos dias da destruição. São Paulo: Editora Filhos da África, 2018.

SILVA, Allyne Andrade e. Direito e políticas públicas quilombolas. Belo Horizonte; São Paulo: D’Plácido, 2020.

SILVA, Givânia Maria. Educação como processo de luta política: a experiência de "educação diferenciada" do território quilombola de Conceição das Crioulas. Dissertação (Mestrado Políticas Públicas e Gestão da Educação) - UnB, Brasília, DF, 2012.

SODRÉ, Muniz. O terreiro e a cidade: a forma social negro-brasileira. Petrópolis: Vozes, 1988. VIEIRA, Priscila Piazentini. Foucault e a vontade de transformar radicalmente a existência. Revista Ecopolítica, São Paulo, n. 7, v. 2, pp. 60-75, set./dez. 2013.

\section{Fontes orais}

FRANCISCO, Marilda de Souza [55 anos]. [fev. 2016]. Entrevistadora: Mariléa de Almeida. Angra dos Reis, RJ, 24, 27, 28 fev. 2016.

Artigo publicado como parte da premiação do II Prêmio ABHO de Teses Ecléa Bosi (2020), no qual a autora recebeu menção honrosa.

Fonte de financiamento: Fundação de Amparo à Pesquisa do Estado de São Paulo (Fapesp).

Conflitos de interesse: nada a declarar. 